\title{
Essentiality with Factor Influencing Accessibility of Zinc in Crops and Human
}

\author{
Samrat Adhikary $^{1 *}$, Bipin Bihari ${ }^{2}$, Ritesh Kundu $^{1}$, Joy Dutta $^{1}$ \\ and Aritra Kumar Mukherjee ${ }^{1}$ \\ ${ }^{1}$ Department of Agricultural Chemistry and Soil Science, Bidhan Chandra Krishi \\ Viswavidyalaya, Mohanpur, Nadia, West Bengal, 741252, India \\ ${ }^{2}$ Department of Soil Science and Agricultural Chemistry, Bihar Agricultural University, \\ Sabour, Bhagalpur, Bihar, 813210, India
}

*Corresponding author

\begin{tabular}{|l|}
\hline K e y w or d s \\
Zinc inadequacy, \\
pH, Organic matter \\
content, Clay \\
content, Sorption- \\
desorption Zinc \\
fertilizer
\end{tabular}

Zinc inadequacy, both in human and plants, have now become a serious issue among the nutritionists, medicinal researchers and agronomists for quite a long time. It is evaluated that $33 \%$ of the total populace is zinc inadequate, bringing about various wellbeing complexities incorporating disabilities in insusceptible framework and mental capacities. Zinc is essential for the proper functioning of a large number of proteins and over 100 specific enzymes in the human body. Zinc deficiency in early life can impair physical and neural growth and development, brain function, memory and learning ability. Severe zinc deficiency is characterized by stunting, lack of normal sexual development, poor immune response, skin disorders, and anorexia. The recommended daily allowance of zinc is $12 \mathrm{mg}$ for adult women and $15 \mathrm{mg}$ for adult men. More than $66 \%$ of the rice become worldwide is delivered on overwhelmed paddy soils, which for the most part contain low sums of plant- available zinc. The soil factors viz., $\mathrm{pH}$, organic matter content, clay content, calcium carbonate content affecting the availability of zinc to plants. Total zinc content, redox conditions, microbial activity in the rhizosphere, soil moisture status, concentrations of other trace elements, concentrations of macro-nutrients, especially phosphorus and climate are also influenced its availability. Zinc can be additionally applied into soils after stronghold of ordinarily applied NPK composts. One-percent zinc-containing NPK and urea manures are accessible in numerous nations. Sufficient and adjusted supplement data sources are basic to delivering and keeping up ideal returns that outcome in most extreme benefit. Zinc fertilizers are broadcast and sprayed onto topsoil, banded in the seedbed, applied as seedlings are dipped into $\mathrm{Zn}$ before transplanting. Zinc sulphate is the commonly used fertilizer compound $\left(\mathrm{ZnSO}_{4}\right.$. $7 \mathrm{H}_{2} \mathrm{O}$ containing $26 \% \mathrm{Zn}$, or $\mathrm{ZnSO}_{4}-\mathrm{H}_{2} \mathrm{O}$ containing $37 \% \mathrm{Zn}$ ). The historical backdrop of zinc in agribusiness is an exceptional showing of the interpretation of research to viable application. In any case, zinc lack in agronomically significant plants creatures still stays an issue around the world, particularly in zones with less created farming practices. 


\section{Introduction}

"... it is estimated that zinc deficiency. Affects about one-third of the world's population...Worldwide, zinc deficiency. Responsible for approximately sixteen percent of lower respiratory infections, eighteen percent of malaria, and ten percent of diarrheal disease...800,000 deaths worldwide were contributed to zinc deficiency" [The World Health Report, 2002(WHO)].

Zinc inadequacy, both in human and plants, have now become a serious issue among the nutritionists, medicinal researchers and agronomists for quite a long time. Be that as it may, it has been getting expanding consideration as of late by different gatherings too, including financial specialists and social researchers, with the acknowledgment this is a worldwide nourishing issue with critical wellbeing, social, and monetary ramifications.

It is evaluated that $33 \%$ of the total populace is zinc inadequate, bringing about various wellbeing complexities incorporating disabilities in insusceptible framework and mental capacities. It is additionally evaluated that around half of the world's farming soils are lacking in zinc, prompting diminished harvest creation and dietary benefit. Further, the consumption of cereal-based foods which are typically low in zinc, contributes up to $70 \%$ of the daily calorie intake in most of the developing countries, thus resulting in the high prevalence of zinc deficiencies in these populations (Cakmak, 2008).

Zinc deficiency in early life can impair physical and neural growth and development, brain function, memory and learning ability. Severe zinc deficiency is characterized by stunting, lack of normal sexual development, poor immune response, skin disorders, and anorexia. Further, it is estimated that zinc deficiency is responsible for nearly 450,000 deaths or $4.4 \%$ of children under the age of five worldwide (Black et al., 2008). According to WHO, zinc deficiency is the fifth leading cause of death and disease in developing nations (WHO, 2002). The global impact in terms of human health has been clearly identified by the Copenhagen Consensus, a group of eight leading economists, including five Nobel Laureates.

Zinc is vital for many biological functions in the human body. The adult body contains 2-3 grams of zinc, present in all parts of the body, including organs, tissues, bones, fluids, and cells (Andreini et al., 2006). Zinc is essential for the proper functioning of a large number of proteins and over 100 specific enzymes in the human body. Zinc also protects human and plant cells from damaging attack of highly toxic free radicals. The recommended daily allowance of zinc for adult women is $12 \mathrm{mg}$, and for adult men, 15 milligrams.

The high predominance of zinc-inadequate soils in major rural zones seriously limits agricultural profitability. Zinc composts can, in this way, make a critical contribution towards objectives of higher harvest yields in sustainable and environmentally responsible way. All the while, zinc fertilizers can upgrade grain zinc concentration and in this way contribute significantly to daily zinc admission of human populations. A study for the Food and Agricultural Organization (FAO) by Sillanpaa discovered that zinc was the most ordinarily deficient micronutrient on the planet. The investigation, which inspected 190 field preliminaries in fifteen nations, found that zinc inadequacy happened in one out of each two preliminaries.

\section{History of zinc}

Zinc consistently has been a noteworthy mineral component for horticulture. Be that as it may, acknowledgment of this importance at 
first grew gradually. The primary sign that zinc could affect horticultural creation showed up in 1869 when Raulin an understudy of Louis Pasteur, detailed that zinc was a necessary supplement for the development of Aspergillus niger, a growth that causes dark form in some rural produce, including grapes, onions, and peanuts.

That striking discovering stayed lethargic until 1911 when Bertrand and Javillier affirmed the finding of Raulin. After three years, it was reported that maize developed by utilizing hydroponic strategies required zinc for development and improvement.

This report animated endeavors to affirm that zinc was required by plants, however the rough techniques and the debasement of as far as anyone knows unadulterated synthetic substances used to develop plants created conflicting outcomes. Therefore, the prerequisite of zinc for vegetation was addressed until 1926 when Sommer and Lipman (1926) indicated that zinc was required for the development and improvement of sunflowers and grain.

\section{Factors affecting the availability of Zinc in} Soils to Plants

The zinc which is available to plants is that present in the soil solution, or is adsorbed in a labile (easily desorbed) form. The soil factors affecting the availability of zinc to plants are those which control the amount of zinc in the soil solution and its sorption-desorption from/into the soil solution.

These factors include: the total zinc content, $\mathrm{pH}$, organic matter content, clay content, calcium carbonate content, redox conditions, microbial activity in the rhizosphere, soil moisture status, concentrations of other trace elements, concentrations of macro-nutrients, especially phosphorus and climate.
Soil types associated with widespread Zinc deficiency in Crops

Although it is recognised that zinc deficiencies in crops can be found on very many types of soils in the different bio-climatic zones of the world, there are a relatively small number of widely occurring types of soil which are more frequently associated with zinc deficiency than any other. These are: parent material of soils and $\mathrm{Zn}$ content, calcareous soils, texture, soil $\mathrm{pH}$, soil organic matter, phosphate fertilizers

\section{Parent material of soils and $\mathrm{Zn}$ content}

The measures of $\mathrm{Zn}$ in unpolluted soils commonly are lower than $125 \mathrm{ppm}$. The main considerations influencing the grouping of $\mathrm{Zn}$ in soils is the convergence of $\mathrm{Zn}$ in soil parent material. The dirts got from gneisses and rocks can be low in complete $\mathrm{Zn}$ and furthermore those starting from sandstone and limestone had lower Zn substance [Barak et al., 1993]. Quartz (sand) in the dirts additionally weakens soil $\mathrm{Zn}$ as groupings of $\mathrm{Zn}$ in quartz are extremely low which range between $1-8 \mu \mathrm{g}$ $\mathrm{g}^{-1 .}$ Likewise complete $\mathrm{Zn}$ is low $\left(<30 \mu \mathrm{g} \mathrm{g}^{-1}\right)$ in profoundly filtered corrosive sands. Zinc inadequacy may happen in such soils which are innately low in $\mathrm{Zn}$. The all out $\mathrm{Zn}$ fixations in soils fluctuate between 10 to $300 \mu \mathrm{g} \mathrm{g}^{-1}$ with a normal of $50 \mu \mathrm{g} \mathrm{g}^{-1}$. But the normal accessible $\mathrm{Zn}$ fluctuated from 1 to $3 \mu \mathrm{g} \mathrm{g}^{-1}$ (separated by dithizone). The issue is that just a modest quantity of soil $\mathrm{Zn}$ is accessible to the harvest as a result of at least one antagonistic element. The rest of the absolute $\mathrm{Zn}$ is fixed in the dirt in an insoluble or unexchangeable structure and hard to make accessible to trim.

\section{Calcareous Soil}

In calcareous soils, $\mathrm{HCO}_{3}$ - is the transcendent anion, which mostly decreases $\mathrm{Zn}$ transport 
from root to shoot, yet less the Zn take-up by roots. Under anaerobic condition $\mathrm{Zn}$ frames an insoluble $\mathrm{Zn}$-phosphate. Under this condition plant roots won't take up the dissolvable $\mathrm{Zn}$ from the $\mathrm{Zn}$ arrangement as required by the plant.

Zinc focuses dynamically diminished with expanding $\mathrm{Ca}$ fixations in arrangements. This finding $\mathrm{Ca}$ hinders $\mathrm{Zn}$ assimilation was as per a transient report directed by Chaudhry and Loneragan (1977). They found that expanding groupings of $\mathrm{Ca}\left(\mathrm{NO}_{3}\right)_{2}$ from $0 \mathrm{mM}$ to $40 \mathrm{mM}$ hindered the pace of $\mathrm{Zn}$ ingestion by wheat seedlings in a non-focused way, in any case, higher $\mathrm{Ca}$ fixations $(100 \mathrm{mM})$ had no extra impact on $\mathrm{Zn}$ assimilation. This restraint was credited to $\mathrm{Ca}$ as fluctuating the anions and had little impact on $\mathrm{Zn}$ assimilation, though substituting other feline particles for $\mathrm{Ca}$ had comparatively negative impact.

\section{Texture}

Lighter texture soils (sands) contain low level of $\mathrm{Zn}$. Better surface soils like clay have higher CEC qualities and in this way have profoundly receptive locales and can hold more $\mathrm{Zn}$ than lighter texture soils. Subsequently heavier texture soils with bigger CEC have higher capacities with regards to $\mathrm{Zn}$ adsorption than light finished soils.

Subsequently, Zn lack is bound to happen in sandy than clayey soils. Clay soils adsorb Zn and this adsorption is constrained by CEC and $\mathrm{pH}$. Reddy et al., Showed that a certain portion of the $\mathrm{Zn}$ adsorbed on the clay was not exchangeable but was acid soluble.

This portion of $\mathrm{Zn}$ was not available to the plants. It was found that kaolonite fixes less $\mathrm{Zn}$ than bentonite or illite. Thus clays such as bentonite and illite with higher CECs contribute to the fixing of $\mathrm{Zn}$ more strongly, thus making it unavailable to plants.

\section{Soil pH}

Zinc accessibility is profoundly reliant on $\mathrm{pH}$. At the point when the $\mathrm{pH}$ is over 6 , the accessibility of $\mathrm{Zn}$ is normally exceptionally low. The accessibility of $\mathrm{Zn}$ in antacid soils is decreased because of lower dissolvability of the dirt $\mathrm{Zn}$. The grouping of $\mathrm{Zn}$ in the dirt arrangement diminishes from $10^{-4}\left(6.5 \mu \mathrm{g} \mathrm{g}^{-1}\right)$ to $10^{-10} \mathrm{M}\left(0.007 \mu \mathrm{g} \mathrm{L}^{-1}\right)$ with an expansion from $\mathrm{pH} 5$ to $\mathrm{pH}$ 8. Along these lines it is progressively likely that Zn lack will happen in basic as opposed to acidic soils. The solvency steady estimations of $\mathrm{ZnCO}_{3}$ and hydroxides propose that a dirt having high $\mathrm{pH}$ would more often than not contain a modest quantity of accessible $\mathrm{Zn}$. On account of soils described by high substance of hydroxyl $\left(\mathrm{OH}^{-}\right)$ particles, it is hard to get a harvest reaction even to applied $\mathrm{Zn}$. The lower accessibility of $\mathrm{Zn}$ under antacid conditions is credited to the precipitation of $\mathrm{Zn}$ as $\mathrm{Zn}(\mathrm{OH})_{2}$ or $\mathrm{ZnCO}_{3}$ (Saeed and Fox, 1977). The higher carbonate substance in soluble soils additionally retains $\mathrm{Zn}$ and holds it in an unexchangeable structure. Every one of these variables add to the low accessibility of $\mathrm{Zn}$ at higher $\mathrm{pH}$ esteems. Liming of acidic soils builds $\mathrm{pH}$ and furthermore the $\mathrm{Zn}$ fixing limit, especially in soils with high $\mathrm{P}$ levels. The development of $\mathrm{Zn}$ in limed soils is significantly lower than in acidic soils with the goal that retention of $\mathrm{Zn}$ by the harvest might be low.

\section{Soil organic matter}

Zinc availability is significantly dependent on $\mathrm{pH}$. Right when the $\mathrm{pH}$ is more than 6 , the availability of $\mathrm{Zn}$ is typically particularly low. The openness of $\mathrm{Zn}$ in acid neutralizer soils is diminished as a result of lower dissolvability of the earth $\mathrm{Zn}$. The gathering of $\mathrm{Zn}$ in the soil course of action decreases from $10^{-4}(6.5 \mu \mathrm{g} \mathrm{g}$ $\left.{ }^{1}\right)$ to $10^{-10} \mathrm{M}\left(0.007 \mu \mathrm{g} \mathrm{L}^{-1}\right)$ with an extension from $\mathrm{pH} 5$ to $\mathrm{pH}$ 8. Thusly all things considered, $\mathrm{Zn}$ need will occur in essential 
instead of acidic soils. The dissolvability relentless estimations of $\mathrm{ZnCO}_{3}$ and hydroxides recommend that an earth having high $\mathrm{pH}$ would as a general rule contain a humble amount of available $\mathrm{Zn}$. By virtue of soils depicted by high substance of hydroxyl $\left(\mathrm{OH}^{-}\right)$particles, it is difficult to get a reap response even to applied $\mathrm{Zn}$. The lower openness of $\mathrm{Zn}$ under stomach settling agent conditions is credited to the precipitation of $\mathrm{Zn}$ as $\mathrm{Zn}(\mathrm{OH})_{2}$ or $\mathrm{ZnCO}_{3}$ (Saeed and Fox, 1977). The higher carbonate substance in solvent soils furthermore holds $\mathrm{Zn}$ and holds it in an unexchangeable structure. All of these factors add to the low openness of $\mathrm{Zn}$ at higher $\mathrm{pH}$ regards. Liming of acidic soils fabricates $\mathrm{pH}$ and moreover the $\mathrm{Zn}$ fixing limit, particularly in soils with high P levels. The advancement of $\mathrm{Zn}$ in limed soils is altogether lower than in acidic soils with the objective that maintenance of $\mathrm{Zn}$ by the reap may be low.

\section{Phosphate fertilizers}

Soils with higher phosphate levels, either from local $\mathrm{P}$ or because of use of phosphate composts, can cause $\mathrm{Zn}$ insufficiency worry in crops. Substantial application or delayed utilization of phosphatic manures diminishes Zn take-up by plants. This impact might be because of the physiological uneven characters inside the plant [Olsen et al., 1977]. Zinc inadequacy because of phosphorus application is named "P-incited $\mathrm{Zn}$ insufficiency".

\section{Area of Zinc deficient in India}

The critical level of $\mathrm{Zn}$ in Indian soils is 0.6 ppm and there is a growing concern that it should be increased to $1.2 \mathrm{ppm}$, or higher, as the intensity of crop production increase. The Food and Agriculture Organization (FAO) has determined that zinc is the most commonly deficient micronutrient in agricultural soils; almost $50 \%$ of agricultural soils are $\mathrm{Zn}$ deficient. Plants growing on potentially zincdeficient soils have reduced productivity and contain very low concentrations of zinc in the edible parts (such as in cereal grains). Therefore, zinc deficiency represents a serious nutritional and health problem in human populations, especially in the developing world where cereal-based foods are the dominating source of diet. Zinc deficiency is widespread in soils and crops worldwide. Almost half of the soils in the world are deficient in $\mathrm{Zn}$ and India is no exception. About $40 \%$ of soil samples analysed for available $\mathrm{Zn}$ were found deficient in India. Significant improvement in crop yield and quality through balanced application of $\mathrm{Zn}$ has been reported across India. Adequate $\mathrm{Zn}$ application to crops is important for the food and nutritional security of India. This above guide of accessible micronutrients in soil help in understanding the degree of micronutrient inadequacy and danger and their judicious the board for feasible creation, improvement in nourishment quality, and creature/human wellbeing. In this manner, global situating framework (GPS) and land data framework (GIS) based region shrewd maps have been set up for different conditions of India for planning the remediation techniques for rectifying micronutrients inadequacies in crops. The investigation of more than 2.0 lakhs soil tests, gathered from 508 regions of the nation during 2011-2017 under the initiative of ICAR - Indian Institute of Soil Science, Bhopal, uncovered that on an average of $36.5,12.8,7.1,4.2$ and $23.2 \%$ soils are lacking in $\mathrm{Zn}, \mathrm{Fe}, \mathrm{Mn}, \mathrm{Cu}$ and $\mathrm{B}$, individually.

\section{Effect of Zn deficiency on plants}

Zinc deficiency is one of the major constraints in world food production. It is therefore essential to identify the $\mathrm{Zn}$-deficient areas, and the different causes of deficiency. It would help in planning the appropriate strategies to correct these $\mathrm{Zn}$ deficiencies. Although $\mathrm{Zn}$ is being used as a fertilizer, an understanding of 
efficient and economical methods to correct $\mathrm{Zn}$ deficiency on a long term basis and in a specific cropping system is desirable. It was reported by that there is a strong relationship between $\mathrm{Zn}$ concentration in tissues with the growth and yield of crops. The critical limits of $\mathrm{Zn}$ in plants indicates deficiency as suggested by are: $<10 \mathrm{mg} \mathrm{kg}{ }^{-1}$ definite $\mathrm{Zn}$ deficiency, 10-15 mg kg-1 very likely, 15-20 $\mathrm{mg} \mathrm{kg}$ likely and $>20 \mathrm{mg} \mathrm{kg}^{-1}$ unlikely (sufficient). In most crop species leaf sufficiency range for $\mathrm{Zn} 15$ to $50 \mathrm{ppm}$ in the dry matter of mature plants and in most cases $15 \mathrm{ppm} \mathrm{Zn}$ is considered as critical value.

Zinc content of the major staple foods such as wheat, rice, maize, and beans is of particular concern. For many people in developing nations, cereals are the principal source of calories, proteins and minerals. Since these are the regions with widespread zinc-deficient soils, these are also the regions with widespread zinc deficiency in humans.

There is a direct and vital link between zinc deficiency in crops and human health in these areas of the world. A study conducted in India documented lower zinc levels (in blood plasma serum) in people feeding on cereal grains with lower zinc content grown in zincdeficient soils (Singh, 2009).

Today, it is assessed that half of rural soils dedicated to grain development are possibly zinc lacking. More than $66 \%$ of the rice become worldwide is delivered on overwhelmed paddy soils, which for the most part contain low sums of plant-accessible zinc. Wheat is regularly developed on basic, calcareous soils with low natural issue in the semiarid (rainfed) areas of the world. These dirt and climactic conditions will in general make zinc less accessible for take-up and use by plants. Under zinc-lacking soil conditions, plants demonstrate a high powerlessness to natural pressure factors, for example, dry spell, heat pressure, and pathogenic contaminations, which invigorate advancement of chlorosis and rot on the leaves and cause hindered development. The high predominance of zinc-inadequate soils in major farming zones seriously limits agricultural profitability. Zinc composts can, consequently, make a critical contribution towards objectives of higher harvest yields in sustainable and environmentally responsible way (Fig. 1-3; Table 1 and 2).

Table.1 Commonly used $\mathrm{Zn}$ sources

\begin{tabular}{|c|c|c|}
\hline Zn Source & Formula or designation & Percent of Zinc \\
\hline Zinc sulfate monohydrate & $\mathrm{ZnSO}_{4} \cdot \mathrm{H}_{2} \mathrm{O}$ & 36 \\
\hline Zinc sulfate heptahydrate & $\mathrm{ZnSO}_{4} \cdot 7 \mathrm{H}_{2} \mathrm{O}$ & 22 \\
\hline Zinc oxysulfate & $\mathrm{xZnSO}_{4} \cdot \mathrm{xZnO}$ & 50 \\
\hline Zinc oxide & $\mathrm{ZnO}$ & 80 \\
\hline Zinc carbonate & $\mathrm{ZnCO}_{3}$ & $50-60$ \\
\hline Zinc chloride & $\mathrm{ZnCl}_{2}$ & 50 \\
\hline Zinc nitrate & $\mathrm{Zn}_{2}\left(\mathrm{NO}_{3}\right) \cdot 3 \mathrm{H}_{2} \mathrm{O}$ & 23 \\
\hline Chelates & $\mathrm{Na}_{2} \mathrm{ZnEDTA}$ & $8-14$ \\
\hline & $\mathrm{NaZnHEDTA}$ & $6-10$ \\
\hline & $\mathrm{NaZnNTA}_{3}$ & $9-13$ \\
\hline Natural organic complexes & $\mathrm{Zn}_{3}\left(\mathrm{C}_{6} \mathrm{H}_{5} \mathrm{O}_{7}\right)_{2} 2 \mathrm{H}_{2} 0$ & $10-18$ \\
\hline Ammoniated zinc & --- & $3-12$ \\
\cline { 2 - 3 } & $\mathrm{Zn}_{2}\left(\mathrm{NH}_{3}\right) 4 \mathrm{SO}_{4}$ & 10 \\
\hline
\end{tabular}

Source:- Mordvedt et al., 1991 
Table.2

\begin{tabular}{|c|c|c|c|c|c|}
\hline Crop & $\begin{array}{c}\text { Zn Rate } \\
\text { (kg/ha) }\end{array}$ & $\begin{array}{c}\text { Zn Cost } \\
\text { (INR/ha) }\end{array}$ & $\begin{array}{c}\text { Yield Increase } \\
\text { (kg/ha) }\end{array}$ & $\begin{array}{c}\text { Value of } \\
\text { Increase }\end{array}$ & $\begin{array}{c}\text { Benefit-to- } \\
\text { Cost Ratio }\end{array}$ \\
\hline Wheat & 5.25 & 875 & 1430 & 20,735 & $24: 1$ \\
\hline Rice & 8.40 & 1400 & 1102 & 14,987 & $11: 1$ \\
\hline Maize & 6.30 & 1050 & 1521 & 19,925 & $19: 1$ \\
\hline Chickpea & 10.00 & 1750 & 855 & 32,063 & $18: 1$ \\
\hline Lentil & 2.62 & 438 & 440 & 16,500 & $38: 1$ \\
\hline Groundnut & 5.50 & 910 & 690 & 25,875 & $28: 1$ \\
\hline Mustard & 6.30 & 1050 & 230 & 8,625 & $8: 1$ \\
\hline Cotton & 5.60 & 945 & 430 & 16,125 & $17: 1$ \\
\hline
\end{tabular}

Procurement / Minimum Support Price in INR/mt (2014-15): Wheat=1450, Rice=1360, Maize=1310,

Chickpea $=3175$, Lentil $=3075$, Groundnut $=4000$, Mustard $=3100$, Cotton $=3750$. Average ZnSO4 heptahydrate price=INR 35/kg (source: Rattan et al., 2008)

Fig.1 Worldwide Zn deficiency in soils and humans (Alloway, 2008).

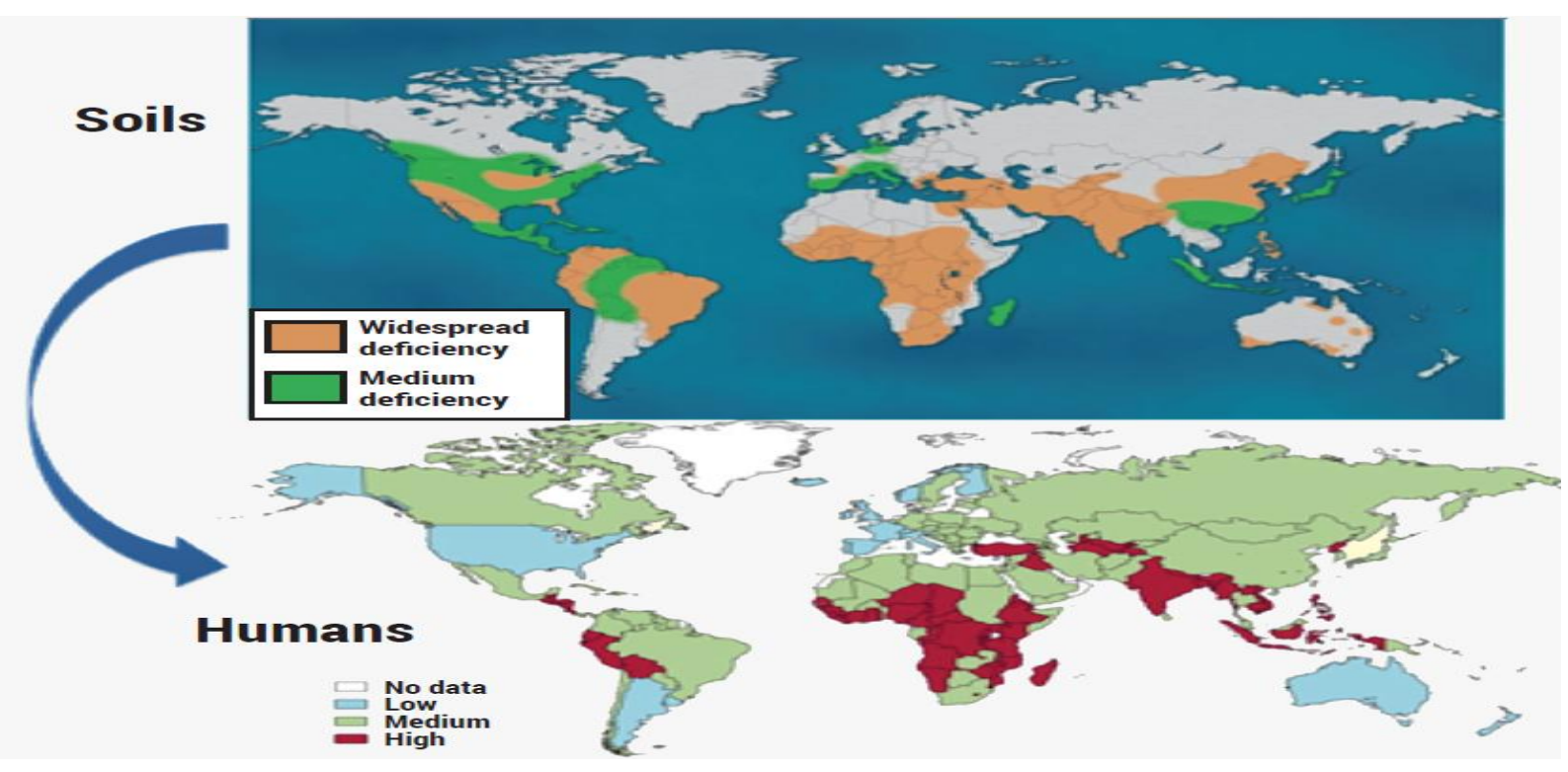


Figure 2: Soil Zinc deficiency status in India (Shukla and Tiwari, 2016)

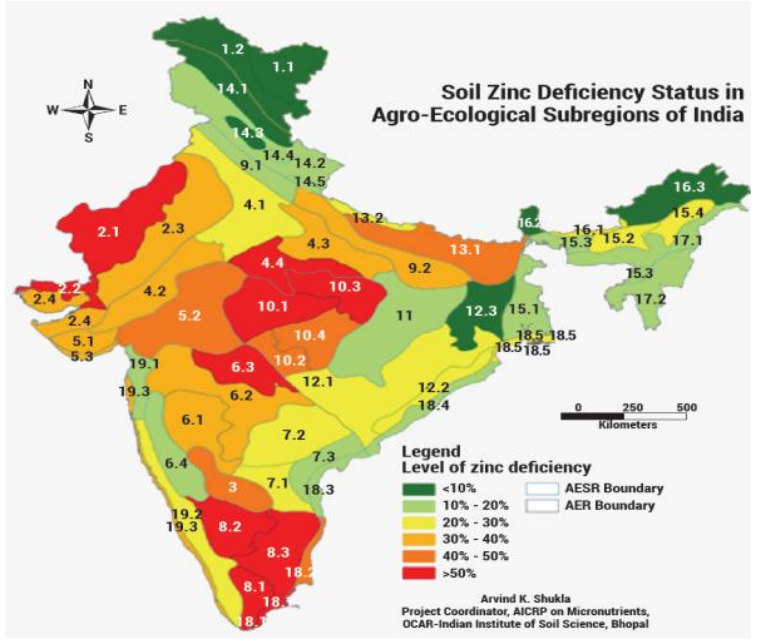

Fig.3

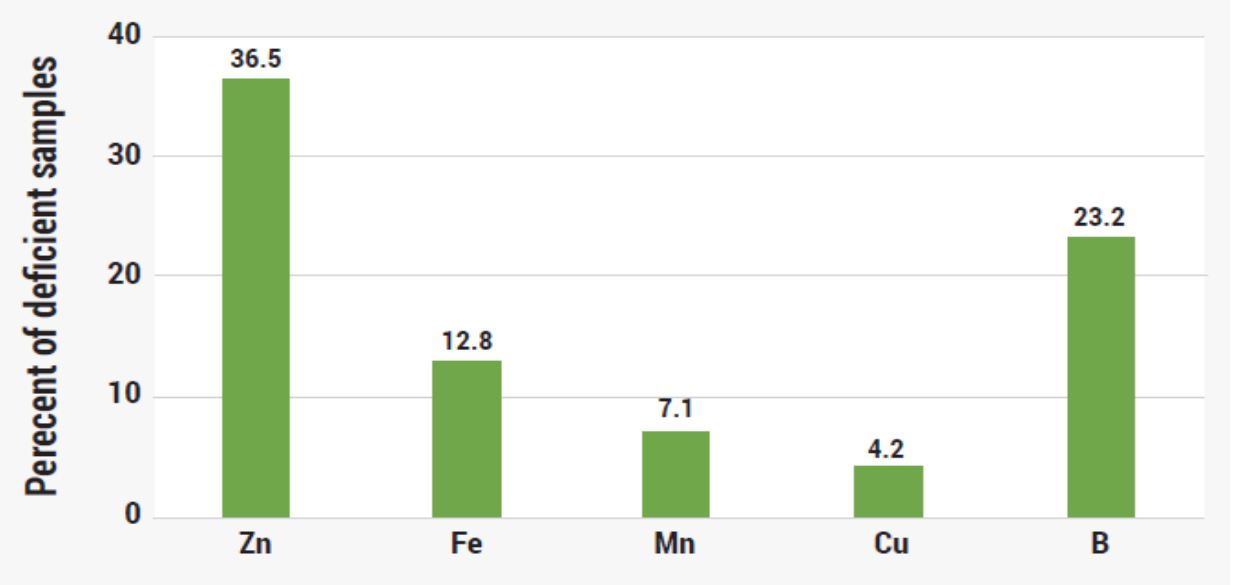

Figure 3: Micronutrient deficiency in Indian soils (2017) 
Figure 4: Schmatic diagram of the cause of Zinc Deficiency in crops (adapted from Alloway, 2008)

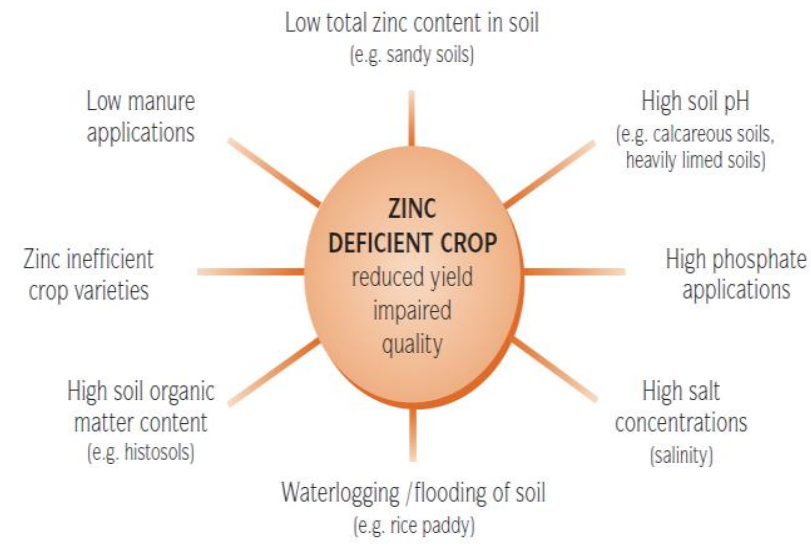

At the same time, zinc fertilizers can improve grain zinc concentration and accordingly contribute significantly to daily zinc admission of human populations. A study for the Food and Agricultural Organization (FAO) discovered that zinc was the most usually deficient micronutrient on the planet. The examination, which examined 190 field preliminaries in fifteen countries, found that zinc lack happened in one out of each two preliminaries.

Zinc insufficiency in sustenance harvests decreases yield limit and brings down the dietary benefit of yields. Zinc is one of the eight follow components that plants requirement for typical development and propagation. About $10 \%$ of all proteins in natural frameworks need zinc for their capacities and structure.

Plants require zinc in little yet basic fixations for a few key capacities, including: film work, photosynthesis, protein amalgamation, phytohormone union (for example auxin), seedling life, sugar arrangement, and guard against infection and biotic stress factors (for example dry season). Notwithstanding when a plant's macronutrients of nitrogen, phosphorous, potassium, and water are met, zinc lack will keep plants from arriving at their maximum capacity.

\section{Zinc fertilization}

Once identified zinc lacking soils can without much of a stretch be treated with zinccontaining composts. A few diverse zinc mixes are utilized as manures, however zinc sulfate is by a wide margin the most broadly utilized material. In light of the differed soil conditions under which zinc can be insufficient, it is in every case best to recognize and treat soils dependent on soil and plant investigation. The pace of soil zinc application changes between 10 to $100 \mathrm{~kg}$ $\mathrm{ZnSO}_{4} .7 \mathrm{H}_{2} \mathrm{O}$ per hectare. Zinc can be additionally applied into soils after stronghold of ordinarily applied NPK composts. Onepercent zinc-containing NPK and urea manures are accessible in numerous nations.

Sufficient and adjusted supplement data sources are basic to delivering and keeping up ideal returns that outcome in most extreme benefit. Albeit thought about a micronutrient, 
legitimate zinc nourishment is similarly as fundamental as some other harvest supplement, enormous or little. Insufficiencies frequently happen when supplements escape balance, decreasing returns and benefits. Because of broad exhaustion of plantaccessible zinc in soils by developing highyielding cultivars, adjusted treatment projects must incorporate zinc applications.

Zinc Fertilizer Compounds - Three distinct kinds of mixes are utilized in zinc manures. These mixes shift extensively in zinc substance, cost and adequacy for crops on various sorts of soils. The wellsprings of zinc include: (1) inorganic mixes, (2) manufactured chelates and (3) regular natural edifices. Inorganic sources include: zinc sulfate, zinc oxide, zinc carbonate, zinc nitrate, and zinc chloride. Zinc sulfate is the most generally utilized zinc manure worldwide and is accessible in both crystalline monohydrate and heptahydrate structures.

Zinc Fertilizer Application-Zinc lacks are regularly adjusted by soil uses of zinc mixes. Foliar splashes are normally utilized on higher worth natural product trees and grape vines and for treating yearly field crops. Different techniques incorporate seed medicines and root-plunging of transplant seedlings (for example in rice generation).

Fertigation is a generally new application strategy where both Zn composts and NPK manures are included to water system water to improve uniform conveyance, homogeneous blending, more prominent accessibility and decreased danger of harm to plants, particularly in semi parched and dry zones.

The measure of zinc manure required relies upon the kind of yield to be developed, the sort of zinc compost utilized and the neighborhood soil conditions. Soil applications are commonly in the range 5-30 $\mathrm{kg}$ zinc/ha, typically as zinc sulfate communicate or showered (in watery arrangement) onto the seedbed.

Higher applications are regularly utilized for crops which are especially delicate to zinc lack, for example, maize. Zinc manures are additionally frequently used to strengthen different composts, including mixed NPK manures. In this application, it is entirely expected to see stronghold rates in the request for $0.5 \%$ to $1.0 \%$ zinc by mass.

Where ranchers are applying zinc manures all the time (either to the dirt or as foliar showers), normal soil or plant investigation ought to be completed to decide if adequate buildups of zinc have gathered in the dirt; hence, zinc applications could be ceased for at least one years. This spares the rancher the cost of the zinc manure application and guarantees that zinc doesn't collect to unfortunately significant levels. Neighborhood master exhortation ought to be looked for on all parts of the administration of the zinc status of soils as a component of a parity way to deal with treatment.

\section{Advantages and impacts of zinc fertilizers}

Yield upgrades are commonly acknowledged when zinc manures are added to soils with low bioavailable zinc levels. Increments in yield will be reliant on various components, including soil physical and concoction synthesis, $\mathrm{pH}$ and metal oxides and levels of natural issue and soil dampness. Yield reaction to zinc has been seen under practically a wide range of soils and agroclimatic zones. Reaction is high in grain crops just as products of the soil crops. Numerous reports are accessible demonstrating critical money saving advantage impacts of zinc composts for asset poor ranchers, particularly in districts where soil zinc lack is of specific concern. 


\section{Challenges in zinc fertilizer use}

Significant challenges looked by ranchers towards use and advancement of zinc compost items are:

Unavailability of zinc manures at the critical moment of the ranchers

Poor nature of zinc manures accessible in the market

Zinc manures under exceptionally disorderly and divided division

Lack of consciousness of the augmentation and special laborers

Lack of consciousness of the ranchers - last mile conveyance

Zinc is basic for the typical sound development and propagation of plants, creatures and people and when the stock of plant-accessible zinc is deficient, crop yields are diminished and the nature of harvest items is as often as possible disabled. Around 30\% of the universes human masses have swear off nourishment ailing in zinc. Zinc need individuals impacts physical improvement, the working of the safe structure, conceptive prosperity and neurobehavioral headway. Indian soils are overwhelmingly insufficient in DTPA extractable Zn. Coarse surface sandy soil, low in natural issue, calcareousness, high yielding grain oat trimming framework with exclusion of $\mathrm{Zn}$ manure emphasizes $\mathrm{Zn}$ insufficiency. Zinc deficiency in crops and humans is a critical issue and a global challenge. The sustainable solution is to apply an adequate and balanced quantity of $\mathrm{Zn}$ in crop production, so that the soil health and food and nutritional security are ensured. This could be achieved by ensuring: 1) availability of new and innovative $\mathrm{Zn}$ fertilizer products for higher use efficiency; 2) timely access to quality $\mathrm{Zn}$ fertilizers; 3) increased stakeholder awareness on $\mathrm{Zn}$ requirement in the soil-plantanimal-human continuum. Customary $\mathrm{Zn}$ fertilizers $\left(\mathrm{ZnSO}_{4} .7 \mathrm{H}_{2} \mathrm{O}\right)$ answered to have low use efficiency of applied $\mathrm{Zn}(1-5 \%)$. Zn proficiency can be characterized as "the capacity of plants to keep up significant returns in soils with low $\mathrm{Zn}$ accessibility". Various instruments are perhaps drawn in with $\mathrm{Zn}$ efficiency. Zinc deficiency is one of the major constraints in world food production. Identification of $\mathrm{Zn}$ deficient areas, and causes would help in planning the appropriate strategies to correct these $\mathrm{Zn}$ deficiencies. Despite the fact that $\mathrm{Zn}$ is generally utilized as compost, however effective and efficient strategies to address its inadequacy on a long haul premise and in a particular editing framework are alluring. Zinc lack can be rectified through the utilization of $\mathrm{Zn}$ composts, reusing crop buildups, regular natural fertilizers and development of $\mathrm{Zn}$ productive genotypes. Zinc fertilizers are broadcast and sprayed onto topsoil, banded in the seedbed, applied as seedlings are dipped into $\mathrm{Zn}$ before transplanting. Zinc sulphate is the commonly used fertilizer compound ( $\mathrm{ZnSO}_{4}$. $7 \mathrm{H}_{2} \mathrm{O}$ containing $26 \% \mathrm{Zn}$, or $\mathrm{ZnSO}_{4^{-}}$ $\mathrm{H}_{2} \mathrm{O}$ containing $37 \% \quad \mathrm{Zn}$ ). Other $\mathrm{Zn}$ compounds are $\mathrm{Zn}$ chloride $\left(\mathrm{ZnCl}_{2}\right)$, $\mathrm{Zn}$ nitrate $\left(\mathrm{Zn}\left(\mathrm{NO}_{3}\right)_{2}\right), \mathrm{Zn}$ oxide $(\mathrm{ZnO}), \mathrm{Zn}$ oxy-sulphate and $\mathrm{Zn}$-coated urea. The vitality of zinc for plants and warm blooded creatures was found $>75$ y back. The primary report of zinc inadequacy in a horticulturally significant animal (swine) that could happen under ranch conditions was $47 \mathrm{y}$ back. Inside $35 \mathrm{y}$ of that report, sustenance scientists, including a huge number who might progress toward becoming Fellows of the American Society for Nutrition, had introduced a moderately complete image of the significance of zinc nourishment in farming. The historical backdrop of zinc in agribusiness is an exceptional showing of the interpretation of research to viable application. 
In any case, zinc lack in agronomically significant plants creatures still stays an issue around the world, particularly in zones with less created farming practices.

\section{References}

Alloway, B.J. 2008. Zinc in Soils and Crop Nutrition. IZA Publications. International Zinc Association, Brussels.

Andreini, C., Banci, L., and Rosato, A. 2006. Zinc through the three domains of life. Journal of Proteome Research 5:31733178.

Barak, P. and Helmke, P.A. 1993. The chemistry of Zinc. In Zinc in Soils and Plants. (ed.) A.D. Robin. Dordecht: Kluwer Academic Publishers.

Bertrand, G., and Javillier M. 1911.The combined influence of zinc and manganese on the development of Aspergillus niger. Comptesrendus de l'Académie des Sciences 152:900-2.

Black, R.E. 2008. Zinc deficiency, infectious disease and mortality in the developing world. Journal of Nutrition 133: 14851489.

Cakmak, I. 2008. Enrichment of soil grains with zinc: agronomic or genetic biofortification? Plant and Soil 302:117.

Chaudhry, F.M., and Loneragan, J.F.1972. Zinc absorption by wheat seedlings. Inhibition by hydrogen ions and micronutrient cat ions. Soil Science Society of America Journal 36:327331.

Katyal, J.C., and Randhawa, N.S.1983. Micronutrients FAO Fertilizer and Plant Nutrition Bullet in 7. Rome. Food and Agriculture Organization of the United Nations.

Madison, W.I., Sommer, A.L., and Lipman C.B. 1926. Evidence on the indispensable nature of zinc and boron for higher green plants. Plant Physiology 1:231-49.

Olsen, S.R. 1972. In "Micronutrients in Agriculture" (JJ.Mortvedt, PM. Giordano, WL. Lindsay, eds.), pp. 243-264.Soil Science Society of America Journal. Madison, Wisconsin.

Raulin, J. 1869. Etudes cliniques sur la vegetation. Annales des sciences naturelles. Botaniqueet biologyvegetale Ser 5.B:93.

Reddy, M.R., and Perkin, H.F.1974.Fixation of $\mathrm{Zn}$ by clay minerals. Soil Science Society of America Journal 38:229230.

Saeed, M., and Fox, R.L. 1977. Relation between suspension $\mathrm{pH}$ and $\mathrm{Zn}$ solubility in acid and calcareous soils. Soil Science 124:199-204.

Shukla, A.K., and Tiwari P.K. 2016. Micro and secondary nutrients and pollutant elements research in India. Progress Report 2014-16. AICRP-MSPE, ICAR-IISS, Bhopal.pp.1-196.

Singh, M.V. 2009. Micronutrient Nutritional Problems in Soils of India and Improvement for Human and Animal Health. Indian Journal of Fertilizers 11-26.

Sommer, A.L., and Lipman, C.B. 1926. Evidence on the indispensable nature of zinc and boron for higher green plants. Plant Physiology 1:231-49.

Stahl, R.S., and James, B.R. 1991.Zinc sorption by B Horizons Soils as a function of pH. Soil Science Society of America Journal 55:1592-1597.

World Health Organization (WHO). 2002. The World Health Report.

Zinc fact sheet Zinc fertilizer overview.2019.The Zinc Nutrient Initiative was launched by The International Zinc Association (IZA) in response to the critical issue of zinc deficiency in soils, crops and humans.

Rattan, R.K., Datta, S.P., and Katyal, J.C. 
2008. Indian J. Fert. 4(12): 93-118

Mortvedt, J.J. 1991. Micronutrient fertilizer technology. In Micronutrients in Agriculture, 2nd ed., Eds. JJ Mortvedt et al., pp 523-548. Soil Science Society of America Journal, Madison, WI, USA.

\section{How to cite this article:}

Samrat Adhikary, Bipin Bihari, Ritesh Kundu, Joy Dutta and Aritra Kumar Mukherjee. 2019. Essentiality with Factor Influencing Accessibility of Zinc in Crops and Human. Int.J.Curr.Microbiol.App.Sci. 8(11): 2158-2170. doi: https://doi.org/10.20546/ijcmas.2019.811.250 